\title{
POSSIBLE BENEFICIAL EFFECTS OF VITAMIN K AND OSTEOCALCIN ON GLUCOSE METABOLISM
}

Büşra Başpınar, Nurcan Yabancı Ayhan

Department of Nutrition and Dietetics, Ankara University Faculty of Health Sciences, Ankara, TURKEY

\begin{abstract}
The role of vitamin $\mathrm{K}$, in bone metabolism and its effects on insulin resistance and Type-2 diabetes, have been discussed. The mechanism of vitamin K's beneficial effect on insulin sensitivity and glucose homeostasis is not yet known. Various biological active molecules such as adiponectin, leptin, and resistin, which is secreted from adipose tissue and have important roles in glucose metabolism, have been proposed to regulate bone metabolism. Some studies have suggested that bone metabolism is also effective on adipose tissue and energy metabolism. It is thought that osteocalcin, a vitamin $\mathrm{K}$ dependent protein is effective in glucose metabolism. The role of Vitamin $\mathrm{K}$ in glucose metabolism is thought to be partly due to the modulation of diabetes-related cytokines and other metabolic risk markers, as inflammation lies at the bottom of chronic metabolic diseases. The aim of this review is to explain the effect of Vitamin K and osteocalcin on glucose metabolism and its possible mechanisms of action.
\end{abstract}

Keywords: Vitamin K, osteocalcin, glucose metabolism, type 2 diabetes, insulin resistance

\section{INTRODUCTION}

Micronutrients have been received as a supplement to health promotion and disease prevention after recognizing their important role in the management of diseases (1). Even moderate deficiencies of micronutrients, which usually act as coenzymes or cofactors in metabolic activities in our bodies, cause serious health problems $(1,2)$. In recent years, it has been determined that micronutrients have a therapeutic effect on many chronic diseases including diabetes $(3,4)$.

The crucial role of Vitamin K in blood coagulation is well known (5). Carl Peter Henrik Dam (6) who discovered Vitamin K, to symbolize its ability to coagulate, named the vitamin as "K". Vitamin K has two natural forms: phylloquinone (Vitamin K1) and menaquinone (Vitamin K2) (2, 7). Phylloquinone, the most important form of dietary Vitamin $\mathrm{K}$, is found in many vegetable oils, fruits, dairy products, and cereals as well as green vegetables (2). While the most important sources of menaquinone in dietary intake are meat, cheese, and eggs, it is mainly produced by intestinal bacteria (8). Besides, phylloquinone can be converted to menaquinone-4 (9). Furthermore, vitamin $\mathrm{K}$ functions as a cofactor for $\gamma$-glutamyl carboxylase enzyme which is essential for the vitamin $\mathrm{K}$ dependent proteins (9).

Previous studies have focused on the role of Vitamin $\mathrm{K}$ in blood coagulation $(5,6)$. Besides its role in blood coagulation, Vitamin $\mathrm{K}$ improves bone health, prevents vascular calcification, and reduces the risk of cardiovascular diseases (10-12). Furthermore, it is considered to have beneficial effects against insulin resistance (13). Recent studies have shown that Vitamin $\mathrm{K}$ increases insulin sensitivity, improves glucose metabolism, and reduces the risk of Type-2 diabetes mellitus (14-18). In a study conducted by Ertaş-Öztürk et al. (19) Vitamin K and glucose metabolism of non-obese healthy individuals were investigated. It is determined that dietary Vitamin $\mathrm{K}$ intake may have a protective effect on insulin resistance. However, another study showed that glucose tolerance was not improved by seven days of Vitamin K supplementation (20). The association between Vitamin $\mathrm{K}$ and Type-2 diabetes mellitus and the way it possibly uses to prevent insulin resistance are unclear. This review aims to explain the effect of Vitamin K on Type- 2 diabetes mellitus and its potential mechanisms.

Address for Correspondence: Büşra Başpınar, Department of Nutrition and Dietetics, Ankara University Faculty of Health Sciences, Ankara, TURKEY

e-mail: busrabaspinar92@gmail.com ORCID: orcid.org/ 0000-0003-0584-2568 Received: 18.03.2020 Accepted: 25.04.2020 • DOI: 10.4274/ tmsj.galenos.2020.07.02.08 Available at: tmsj.trakya.edu.tr 


\section{The Relationship Between Glucose Metabolism and Vitamin $K$}

Diet and lifestyle play an important role in the progression of insulin resistance, a metabolic disorder in which hepatic and peripheral tissues are less susceptible to insulin (21). In recent years, there have been studies proposing that Vitamin $\mathrm{K}$ intake or deficiency was related to insulin resistance (14-16). The mechanism of vitamin $\mathrm{K}$ on insulin sensitivity and glucose homeostasis are not yet known (2). Various biological active molecules such as adiponectin, leptin and, resistin (22-24), which are secreted from adipose tissue and have important roles in glucose metabolism, have been proposed to regulate bone metabolism. Some studies have suggested that bone metabolism is effective on adipose tissue and energy metabolism $(25,26)$. Many studies have suggested that osteocalcin which is a vitamin $\mathrm{K}$ dependent protein, is effective in regulating glucose metabolism $(9,15,25)$. It has been determined that osteocalcin stimulates $\beta$-cell proliferation, insulin secretion, and insulin sensitivity by stimulating adiponectin secretion (25).

Bone and glucose metabolism are linked by a complex metabolism that contains leptin, osteocalcin, and adiponectin (27). The possible effects of Vitamin K intake and osteocalcin on glucose metabolism are shown in Figure 1.

Osteocalcin is a Vitamin- $\mathrm{K}$ dependent protein synthesized by osteoblasts (7). It has been thought that osteocalcin is the most common non-collagen protein in the bone and its concentration is positively correlated with osteoblast function and Vitamin K availability (12). Vitamin K acts as the cofactor of the gamma-glutamyl carboxylase enzyme which is essential for the synthesis of osteocalcin (Figure 2). Osteocalcin contains a propeptide recognition site for binding gamma-carboxyglutamate (13). After carboxylation, the propeptide is separated and active osteocalcin is synthesized (28). Gamma-carboxyglutamate residues in the osteocalcin are responsible for the shape, size, and bone metabolism of the bone mineral $(7,10)$.

Studies have described three forms of osteocalcin: carboxylated, uncarboxylated and undercarboxylated osteocalcin (7). The difference between uncarboxylated and undercarboxylated osteocalcin has not yet been clearly explained. However, it has generally been reported that high serum undercarboxylated or uncarboxylated osteocalcin is associated with the low levels of Vitamin K (10). Although changes in the concent- ration of undercarboxylated osteocalcin have been reported not to affect glucose metabolism, many researchers have reported that the active form of osteocalcin is undercarboxylated $(7,27)$. It was reported that Vitamin K supplementation (K1 or K2) decreased the level of non-carboxylated osteocalcin, increased the level of carboxylated osteocalcin, and reduced insulin resistance in patients with the high risk of Type- 2 diabetes (10). As a result of a study of 348 non-diabetic men and women for three years, Shea et al. (29) reported that uncarboxylated osteocalcin was not associated with higher insulin resistance whereas low carboxylated osteocalcin was associated with higher insulin resistance. However, Hwang et al. (30) suggested that both carboxylated and non-carboxylated osteocalcin levels improved glucose tolerance.

Lee et al. (31) investigated the endocrine regulation of energy metabolism by the skeleton. In that study, the osteocalcin gene was inactivated in mice. Visceral fat accumulation was impaired and the hyperglycemic state and impaired glucose tolerances were due to insulin resistance and insulin deficiency. It was found that osteocalcin increased beta-cell proliferation, insulin release, and sensitivity by stimulating insulin and adiponectin in beta-cells and adipocytes. Mice that could not produce osteocalcin were found to be obese, had low beta-cell proliferation, and developed insulin resistance (31). In another study, Vitamin K2 supplementation at different doses in rats during 8 weeks period increased the expression of osteocalcin, insulin 1, insulin 2, cyclin D2, which are the indicators of B-cell proliferation (32). Some amino acids and sizes of osteocalcin in mice and humans are different $(27,33)$. The roles of osteocalcin in glucose metabolism in in-vitro and in-vivo studies should be supported with human studies. Human and animal studies should be examined together to make a general conclusion. Table 1 summarizes human and animal studies investigating the effects of vitamin $\mathrm{K}$ and/or osteocalcin on glucose metabolism. 


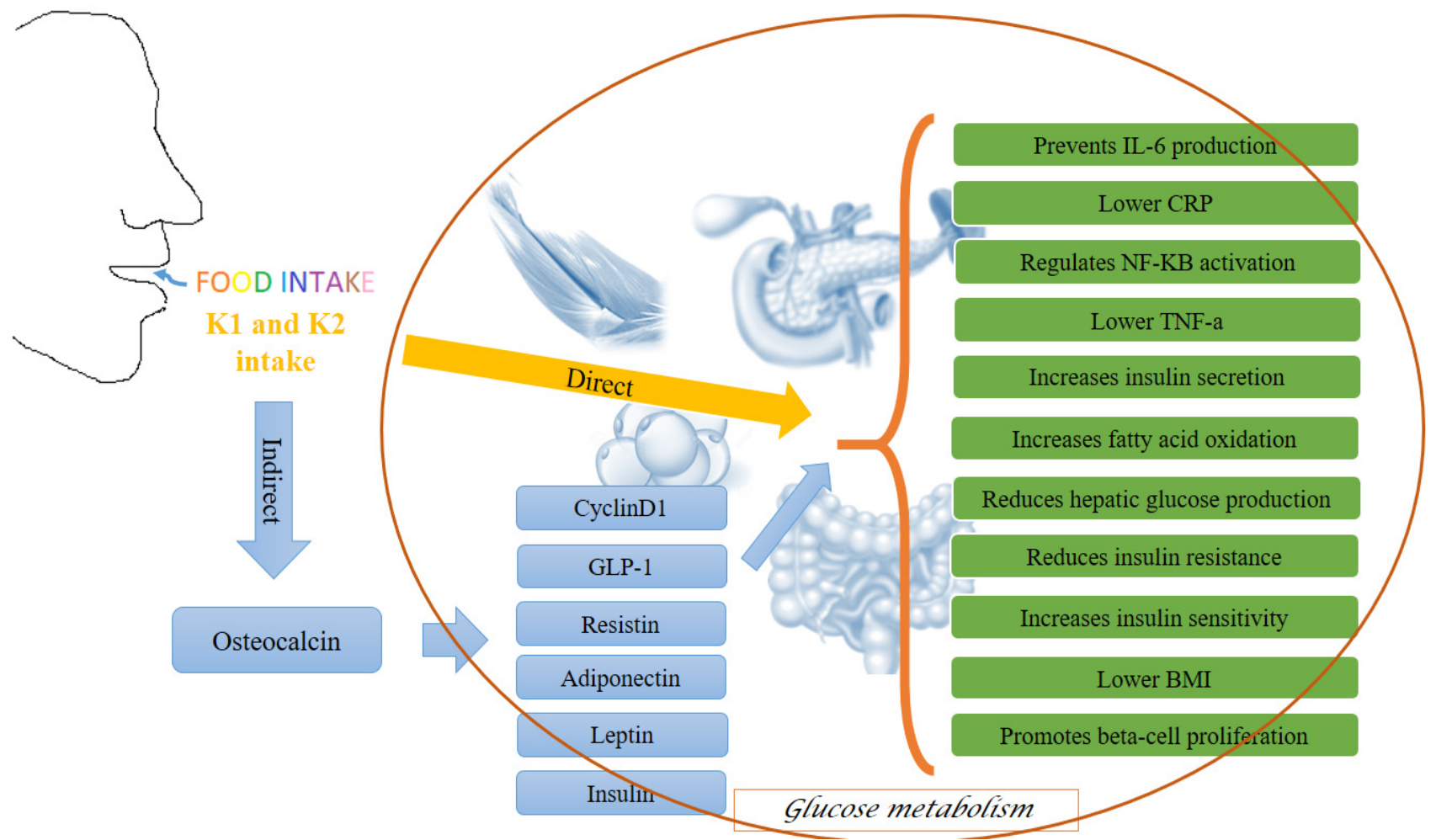

Figure 1: Possible direct and indirect mechanisms of Vitamin K and osteocalcin on glucose metabolism.

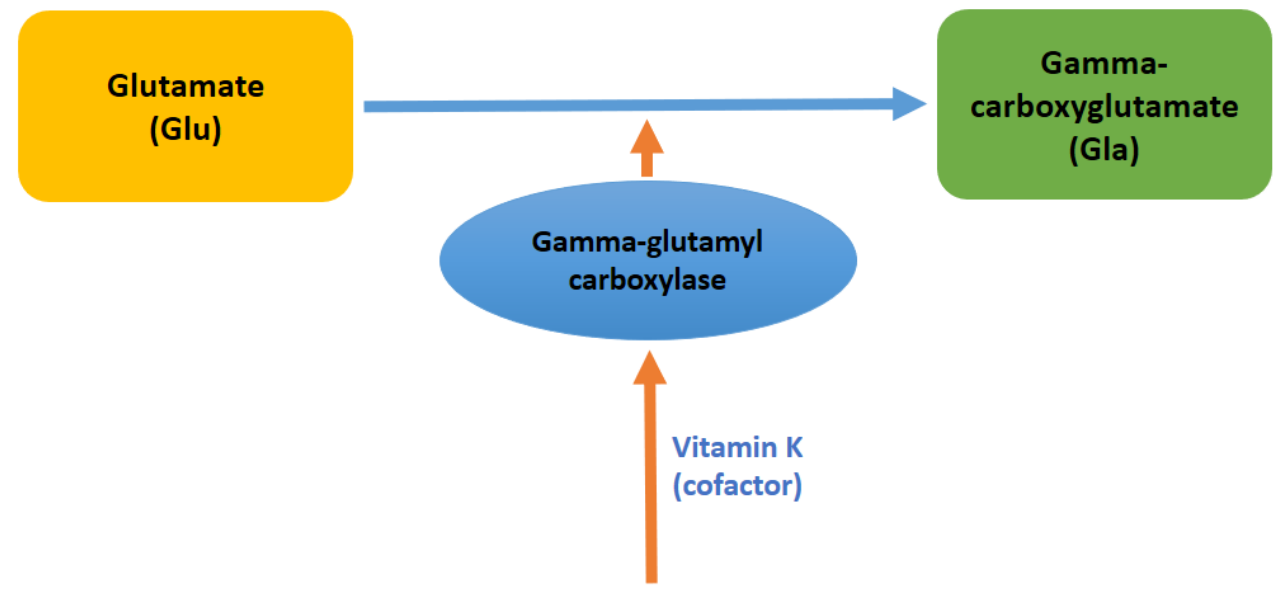

\section{Dietary Viamin K ntake}

Figure 2: Vitamin $K$ is a cofactor for gamma-glutamyl carboxylase. 
Table 1: Effects of Vitamin K and/or osteocalcin on glucose metabolism.

\begin{tabular}{|c|c|c|}
\hline Study & Participants and design & Outcomes \\
\hline $\begin{array}{l}\text { Beulens et } \\
\text { al. (14) }\end{array}$ & $\begin{array}{l}\text { The levels of intake of Vitamin K1 } \\
\text { and Vitamin K2 were evaluated by } \\
\text { food frequency questionnaire which } \\
\text { was questioned for the last } 1 \text { year of } \\
38094 \text { Dutch men and women aged } \\
21-64 \text { years. }\end{array}$ & $\begin{array}{l}\text { Each } 10 \text {-mcg increment of menaquinone intake was } \\
\text { associated with a } 7 \% \text { decrease in the risk of Type } 2 \\
\text { diabetes. }\end{array}$ \\
\hline $\begin{array}{l}\text { Ibarrola- } \\
\text { Jurado et } \\
\text { al. (15) }\end{array}$ & $\begin{array}{l}2353 \text { male diets were followed for a } \\
\text { mean of } 5.5 \text { years. }\end{array}$ & $\begin{array}{l}\text { The dietary intake of phylloquinone every } 100 \mathrm{mcg} / \mathrm{day} \\
\text { was associated with a } 17 \% \text { lower incidence of diabetes. }\end{array}$ \\
\hline $\begin{array}{l}\text { Kunar et } \\
\text { al. (16) }\end{array}$ & $\begin{array}{l}\text { During postmenopausal period, } 1 \\
\text { mg/day phylloquinone } \\
\text { supplementation was performed for } \\
12 \text { months. }\end{array}$ & $\begin{array}{l}\text { There was no significant difference in fasting blood } \\
\text { glucose, insulin concentration and HOMA-IR levels in the } \\
\text { control group. }\end{array}$ \\
\hline $\begin{array}{l}\text { Rasekhi et } \\
\text { al. (17) }\end{array}$ & $\begin{array}{l}\text { In a randomized controlled study of } \\
82 \text { prediabetic women supplemented } \\
\text { with Vitamin } K 1 \text { for } 4 \text { weeks. }\end{array}$ & $\begin{array}{l}\text { According to the control group, fasting blood glucose and } \\
\text { insulin concentration were lower in patients who received } \\
\text { supplemental treatment, but insulin resistance (HOMA-IR) } \\
\text { was not affected. }\end{array}$ \\
\hline $\begin{array}{l}\text { Yoshida et } \\
\text { al. (18) }\end{array}$ & $\begin{array}{l}\text { Dietary Vitamin } K \text { intake of } 2719 \\
\text { individuals was evaluated by the } \\
\text { food frequency questionnaire. }\end{array}$ & $\begin{array}{l}\text { Higher phylloquinone intake was determined to have } \\
\text { higher insulin sensitivity and better glycemic control. }\end{array}$ \\
\hline $\begin{array}{l}\text { Saleem et } \\
\text { al. (26) }\end{array}$ & $\begin{array}{l}\text { Serum osteocalcin levels of } 1209 \\
\text { white people and } 1284 \text { black people } \\
\text { were measured. }\end{array}$ & $\begin{array}{l}\text { There was a relationship between serum osteocalcin levels } \\
\text { and BMI, fasting blood glucose, insulin resistance, leptin, } \\
\text { and adiponectin levels, which had a statistically } \\
\text { significant difference. }\end{array}$ \\
\hline $\begin{array}{l}\text { Shea et al. } \\
\text { (29) }\end{array}$ & $\begin{array}{l}348 \text { non-diabetic individuals were } \\
\text { followed for three years. }\end{array}$ & $\begin{array}{l}\text { Higher levels of carboxylated osteocalcin were associated } \\
\text { with lower fasting blood glucose, insulin resistance, and } \\
\text { higher adiponectin levels. }\end{array}$ \\
\hline $\begin{array}{l}\text { Hwang et } \\
\text { al. (30) }\end{array}$ & $\begin{array}{l}\text { Serum osteocalcin levels of } 199 \text { men } \\
\text { were measured. }\end{array}$ & $\begin{array}{l}\text { Increased levels of both carboxylated and non- } \\
\text { carboxylated osteocalcin were found to improve glucose } \\
\text { tolerance in patients with impaired glucose tolerance. }\end{array}$ \\
\hline $\begin{array}{l}\text { Hussein et } \\
\text { al. (32) }\end{array}$ & $\begin{array}{l}\text { Vitamin } K 2 \text { supplementation was } \\
\text { performed at different doses to } 30 \\
\text { rats for } 8 \text { weeks. }\end{array}$ & $\begin{array}{l}\text { Osteocalcin, insulin 1, insulin 2, Cyclin D2 expressions } \\
\text { were determined to increase. }\end{array}$ \\
\hline $\begin{array}{l}\text { Sakamato } \\
\text { et al. (34) }\end{array}$ & $\begin{array}{l}\text { Dietary Vitamin } K \text { intakes of } \\
\text { indiviahuals were determined by food } \\
\text { frequency questionnaire. }\end{array}$ & $\begin{array}{l}\text { The group receiving low dietary phylloquinone intake had } \\
\text { lower insulin and higher blood glucose concentration. }\end{array}$ \\
\hline $\begin{array}{l}\text { Yoshida et } \\
\text { al. (35) }\end{array}$ & $\begin{array}{l}\text { In a randomized, double-blind } \\
\text { controlled study, the elderly and } \\
\text { non-diabetic } 355 \text { individuals } \\
\text { underwent phylloquinone } \\
\text { supplementation for } 36 \text { months. }\end{array}$ & $\begin{array}{l}\text { HOMA-IR levels were found to be lower in the elderly } \\
\text { than in the control group. }\end{array}$ \\
\hline
\end{tabular}

\begin{tabular}{|c|c|c|}
\hline $\begin{array}{l}\text { Pittas et } \\
\text { al. }(36)\end{array}$ & $\begin{array}{l}\text { Serum osteocalcin levels of } 380 \\
\text { individuals over } 65 \text { years of age } \\
\text { were measured. }\end{array}$ & $\begin{array}{l}\text { Serum osteocalcin concentration was strongly correlated } \\
\text { with plasma fasting glucose, insulin resistance, IL-6, body } \\
\text { mass index (BMI) and body fat. }\end{array}$ \\
\hline $\begin{array}{l}\text { Pollock et } \\
\text { al. (37) }\end{array}$ & $\begin{array}{l}\text { Osteocalcin levels of } 140 \text { overweight } \\
\text { prepubertal children with } \\
\text { prediabetes and normal glucose } \\
\text { levels were measwred. }\end{array}$ & $\begin{array}{l}\text { Low osteocalcin levels were found to be related to } B \text {-cell } \\
\text { dysfunction in children with prediabetes. }\end{array}$ \\
\hline $\begin{array}{l}\text { Asemi et } \\
\text { al. }(38)\end{array}$ & $\begin{array}{l}\text { Vitamin } D \text {, Vitamin } K \text { and calcium } \\
\text { (Ca) were supplemented to } 66 \\
\text { diabetic patients. }\end{array}$ & $\begin{array}{l}\text { Insulin concentrations, insulin resistance (HOMA-IR) and } \\
\beta \text {-cell function were significantly different from the } \\
\text { placebo group. }\end{array}$ \\
\hline $\begin{array}{l}\text { Choi et al. } \\
\text { (39) }\end{array}$ & $\begin{array}{l}\text { Menakinon-4 supplements were } \\
\text { administered to } 42 \text { healthy adults. }\end{array}$ & $\begin{array}{l}\text { In the K2-supplemented group, the level of carboxylated } \\
\text { osteocalcin increased and insulin sensitivity improved } \\
\text { compared to the placebo group. }\end{array}$ \\
\hline $\begin{array}{l}\text { Juanola- } \\
\text { Falgarona } \\
\text { et al. (40) }\end{array}$ & $\begin{array}{l}\text { Dietary Vitamin } K \text { intake of } 510 \\
\text { elderly people was followed for a } \\
\text { year. }\end{array}$ & $\begin{array}{l}\text { Diabetes-related inflammatory cytokines in those who } \\
\text { increase dietary intake of Vitamin } K \text { decreased. }\end{array}$ \\
\hline $\begin{array}{l}\text { Varsha } \\
\text { al. (41) }\end{array}$ & $\begin{array}{l}\text { Rats with Type-1 DM were } \\
\text { supplemented with Vitamin } K 1 \text { twice } \\
\text { a week for } 3 \text { months. }\end{array}$ & $\begin{array}{l}\text { Activation of proinflammatory genes and beta-islet } \\
\text { necrosis were prevented Beta-cell proliferation is } \\
\text { facilitated. }\end{array}$ \\
\hline $\begin{array}{l}\text { Liang et } \\
\text { al. (42) }\end{array}$ & $\begin{array}{l}1049 \text { non-diabetic and } 983 \\
\text { participants followed for four years. }\end{array}$ & $\begin{array}{l}\text { People with impaired glucose metabolism have low } \\
\text { osteocalcin level. }\end{array}$ \\
\hline
\end{tabular}


In epidemiological studies, dietary or supplementary intake of Vitamin K has been shown to reduce insulin resistance and improve glycemic levels $(29,34,36$, 37). Sakamoto et al. (34) evaluated the insulin responses depending on the intake of Vitamin $\mathrm{K}$ in the diet of participants who have normal body weight. It was determined that the group receiving low phylloquinone had lower insulin and higher blood glucose concentration. In a study conducted by Beulens et al. (14), each 10 -mcg increase of menaquinone intake with diet was associated with a $7 \%$ reduction in the risk of Type- 2 diabetes. The effect of vitamin $\mathrm{K}$ on glucose metabolism has often been associated with osteocalcin.

Low osteocalcin level is a risk factor for impaired glucose metabolism and Type-2 diabetes (42). However, in a study, no correlation was found between osteocalcin and glucose levels in patients with normal glucose tolerance (35). These studies demonstrate that the level of osteocalcin is closely related to glucose metabolism.

In a study performed by Saleem et al. (26), a significant relationship was found between serum osteocalcin levels and BMI, fasting blood glucose, insulin resistance, leptin, and adiponectin levels. Another study on older people showed that serum osteocalcin levels were associated with glucose metabolism, serum osteocalcin concentration was strongly correlated with plasma fasting glucose, insulin resistance, IL-6, body mass index and body fat (36). Pollock et al. (37) reported that osteocalcin is associated with glucose metabolism, and this relationship is associated with beta-cell functions. This study was conducted on prepubertal children. Although these studies focused on different age groups, the results were found to be compatible with each other.

Not only cross-sectional studies, but also longitudinal studies showed that Vitamin $\mathrm{K}$ and osteocalcin were effective in glucose metabolism. In a long-term follow-up study, dietary intake of $100 \mathrm{mcg}$ /day was associated with a $17 \%$ lower incidence of diabetes (15). In another follow-up study showed that low osteocalcin level was associated with impaired glucose metabolism (42). The strong relationship between vitamin K, osteocalcin, and glucose metabolism has been supported by these longitudinal studies.

Studies evaluating dietary vitamin $\mathrm{K}$ intake have shown beneficial effects on glucose metabolism. In addition to dietary intake, there are studies evaluating vitamin $\mathrm{K}$ intake as a supplement. In a recent study, 66 diabetic patients received Vitamin D, Vitamin K, and calcium supplementation. In this randomized, double-blind, placebo-controlled study, it was determined that insulin concentrations, insulin resistance (HO-
MA-IR) and $\beta$-cell function showed significant differences compared to the placebo group (38). Choi et al. (39) evaluated insulin sensitivity by giving menaquinone-4 supplements to healthy young men for 4 weeks. It was determined that the level of osteocalcin and insulin sensitivity were higher than the placebo group in the supplemented group.

Since various forms of vitamin $\mathrm{K}$ are used, these studies are open to interpretation. In Rasekhi et al.s study (17) Vitamin K1 supplementation was given to prediabetic women for 4 weeks. According to the control group, the fasting blood glucose levels and the insulin concentration were lower but the insulin resistance (HOMA-IR) was not affected. In another study conducted on 21 women during the postmenopausal period, $1 \mathrm{mg} /$ day phylloquinone supplementation was given for 12 months. However, there was no significant difference in fasting blood glucose, insulin concentration, and HOMA-IR levels compared to the control group (16). In that study, although supplementation was performed for a longer period, it was not effective on insulin resistance, which is accepted as the initial stage of diabetes mellitus (16). In a recent meta-analysis, similarly, it was reported that Vitamin K supplementation does not affect insulin sensitivity (43). The lack of beneficial effects of these results on glucose metabolism as much as dietary intake suggests that the synthetic form of vitamin $\mathrm{K}$ may be ineffective.

It has been reported that studies supplementing animals may be useful in contradiction to human studies. Intraperitoneal undercarboxylated osteocalcin injection is known to affect glucose metabolism by increasing insulin secretion (44). In a study by Mizokami et al. (45), it was stated that GLP-1, one of the incretin hormones, increased the secretion of insulin by increasing intraperitoneal undercarboxylated osteocalcin injection in mice.

\section{The Relationship Between Inflammation and Vitamin $K$}

The role of Vitamin $\mathrm{K}$ in glucose metabolism is thought to be partly due to the modulation of diabetes-related cytokines and other metabolic risk markers (40). In addition, inflammation lies at the bottom of chronic metabolic diseases (46). Vitamin K causes a decrease in free radicals as a potential antioxidant (47). In vitro studies have shown that Vitamin $\mathrm{K}$ decreases the production of proinflammatory cytokines $(40,48$, 49). Although it is not known how Vitamin $\mathrm{K}$ affects inflammation biomarkers, it is thought to suppress inflammation by decreasing the gene expression of cy- 
tokines such as IL-6 (48). Additionally, it is known to have a protective effect against oxidative stress (50).

In a study on type- 1 diabetic rats, Vitamin K1 treatment inhibited Nuclear Factor Kappa B (NF-KB) activation. This treatment is thought to possibly prevent beta-islet necrosis, favor beta-cell proliferation/regeneration, increase insulin production, and decrease hyperglycemia. Therefore, it is thought that Vitamin K1 supplementation may be beneficial for the complications of diabetes, not only for Type- 1 diabetes, but also for beta-cell damage (41). It has been determined that the expression of genes involved in the acute inflammatory response is increased in Vitamin $\mathrm{K}$ deficient rats (48). Additionally, phylloquinone was found out to inhibit the activation of pro-inflammatory genes and prevent oxidative stress (41). In a study conducted on 1381 individuals, low plasma phylloquinone levels were associated with high pro-inflammatory markers (CRP and IL-6) (46).

In a study conducted on 379 healthy subjects, at three years follow up, it was determined that subjects with high cytokine concentration were associated with inadequate dietary Vitamin K (29). However, there was no significant difference in the concentration of cytokines such as IL-6 and CRP in individuals receiving phylloquinone supplementation (29). In a study conducted by Juanola-Falgarona et al. (40) on 510 people, the relationship between dietary Vitamin $\mathrm{K}$ intake and insulin-related peripheral adipokines and other metabolic risk markers related to Type-2 diabetes were investigated. It was determined that inflammatory cytokines such as leptin, tumor necrosis factor (TNF), interleukin (IL) -6 as well as other metabolic risk factors such as ghrelin, glucagon-like peptide-1, and visfatin were significantly decreased in the elderly who increased their phylloquinone intake for a year.

\section{Reasons For Inconsistencies In The Studies}

Human and animal osteocalcin genes differ from each other (33). The Vitamin K-associated osteocalcin gene is upregulated in humans with Vitamin D while it is downregulated in mice (33). Also, some amino acids and the levels of osteocalcin in mice and humans are different $(27,33)$. These differences seen in human and animal studies are attributed to serum osteocalcin level with age, growth, access to skeletal maturity and changes in day to day with menopause (51). In humans, non-carboxylated osteocalcin may occur as a result of decarboxylation during optimal Vitamin $\mathrm{K}$ uptake or osteoclast absorption (10). This situation may also cause contradictions. The food frequency qu- estionnaires used in epidemiological studies were not sensitive enough to differentiate the phylloquinone and menaquinone intake. The reasons for the inconsistency of the results of the studies are thought to be the differences in the distribution and metabolism of menaquinone and phylloquinone in the body. In addition to sufficient positive effects of vitamin K taken as a supplement on people's glucose metabolism have not been observed.

\section{CONCLUSION}

The role of Vitamin $\mathrm{K}$ and osteocalcin on glucose metabolism and its possible mechanisms of action have been discussed in this review. Although the mechanism of action is not clearly understood, Vitamin $\mathrm{K}$ has been shown to reduce the risk of insulin resistance. It is thought that especially the menaquinone form prevents Type- 2 diabetes. Despite the fact that there are many in vivo studies performed in mice, further human studies are required on this subject.

\section{Ethics Committee Approval: N/A \\ Informed Consent: N/A}

Conflict of Interest: The authors declared no conflict of interest.

Author contributions: Concept: BB. Design: BB. Supervision: NYA. Resources: NYA. Materials: BB. Data collection and/or processing: BB. Analysis and/or Interpretation: NYA. Literature Search: BB. Writing Manuscript: BB, NYA. Critical Review: BB, NYA.

Financial disclosure: The authors declared that this study received no financial support.

\section{REFERENCES}

1. Shenkin A. Micronutrients in health and disease. Postgraduate Medical Journal 2006;82:559-67.

2. Manna P, Kalita J. Beneficial role of vitamin K supplementation on insulin sensitivity, glucose metabolism, and the reduced risk of type 2 diabetes: A review. Nutrition 2016;32:732-9.

3. Ghishan FK, Kiela PR. Vitamins and minerals in inflammatory bowel disease. Gastroenterology Clinics of North America 2017;46(4):797-808.

4. Ishihara J, Umesawa $\mathrm{M}$, Okada $\mathrm{C}$ et al. Relationship between vegetables and fruits (Antioxidant vitamins, minerals, and fiber) intake and risk of cardiovascular disease. In: Vasan RS, Sawyer DB, editors. Encyclopedia of Cardiovascular Research and Medicine. Elsevier; 2018.p.253-82.

5. Tie JK, Jin DY, Straight DL et al. Functional study of the vitamin K cycle in mammalian cells. Blood 2011;117(10):2967-74. 
6. Dam H. The antihaemorrhagic vitamin of the chick. Biochem J 1935;29(6):1273-85.

7. Li Y, Chen J peng, Duan L et al. Effect of vitamin K2 on type 2 diabetes mellitus: A review. Diabetes Research and Clinical Practice 2018;136:39-51.

8. Beulens JWJ, Booth SL, Van Den Heuvel E et al. The role of menaquinones (vitamin K 2 ) in human health. Br J Nutr 2013;110(8):112.

9. Shearer MJ, Fu X, Booth SL. Vitamin K Nutrition, metabolism, and requirements: Current concepts and future research. Adv Nutr 2012;3(2):182-95.

10. Booth SL, Centi A, Smith SR et al. The role of osteocalcin in human glucose metabolism: Marker or mediator? Nature Reviews Endocrinology 2013;9(1):43-55.

11. Cranenburg ECM, Schurgers LJ, Vermeer C. Vitamin K: The coagulation vitamin that became omnipotent. Thromb Haemost 2007;98(1):120-5.

12. Knapen MH, Braam LA, Drummen NE et al. Menaquinone-7 supplementation improves arterial stiffness in healthy postmenopausal women. A double-blind randomised clinical trial. Thromb Haemost 2015;113(5):1135-44.

13. Rees $\mathrm{K}$, Guraewal S, Wong YL et al. Is vitamin K consumption associated with cardio-metabolic disorders? A systematic review. Maturitas 2010;67(2):121-8.

14. Beulens JWJ, Van Der A DL, Grobbee DE et al. Dietary phylloquinone and menaquinones intakes and risk of type 2 diabetes. Diabetes Care. 2010;33(8):1699-705.

15. Ibarrola-Jurado N, Salas-Salvadó J, Martínez-González MA et al. Dietary phylloquinone intake and risk of type 2 diabetes in elderly subjects at high risk of cardiovascular disease. Am J Clin Nutr 2012;96(5):1113-8.

16. Kumar R, Binkley N, Vella A. Effect of phylloquinone supplementation on glucose homeostasis in humans. Am J Clin Nutr 2010;92(6):1528-32.

17. Rasekhi H, Karandish M, Jalali MT et al. The effect of vitamin K1 supplementation on sensitivity and insulin resistance via osteocalcin in prediabetic women: A double-blind randomized controlled clinical trial. Eur J Clin Nutr 2015;69(8):891-5.

18. Yoshida M, Jacques PF, Meigs JB et al. Effect of vitamin K supplementation on insulin resistance in older men and women. Diabetes Care 2008;31(11):2092-6.

19. Ertaş-Öztürk Y, Gezmen-Karada M, Aktürk M et al. Body mass index and insulin resistance in healthy adults: As-sociations with plasma osteocalcin, phylloquinone levels, and dietary vitamin $\mathrm{K}$ intake. Prog Nutr 2020;22(2).

20. Dahlberg S, Larsson D, Rommer A et al. Vitamin K2 (Menaquinone-7) supplementation and its effect on glucose tolerance test in healthy volunteers. J Diabetes Metab Manag 2019;1:1-5.

21. Reaven GM. The insulin resistance syndrome: Definition and dietary approaches to treatment. Annu Rev Nutr 2005;25(1):391-406.

22. Al-Osami MH, Hameed EK. Serum adiponectin level in osteoporotic postmenopausal women with type 2 diabetes mellitus. Diabetes
Metab Syndr Clin Res Rev 2018;12(6):939-42.

23. Savvidis C, Tournis S, Dede AD. Obesity and bone metabolism. Hormones 2018;17:205-17.

24. Wu J, Xu J, Wang K et al. Associations between circulating adipokines and bone mineral density in patients with knee osteoarthritis: A cross-sectional study. BMC Musculoskelet Disord 2018;19:16.

25. Lee M, Lee H, Kim J. Dairy food consumption is associated with a lower risk of the metabolic syndrome and its components: A systematic review and meta-analysis. British Journal of Nutrition 2018;120:373-84.

26. Saleem U, Mosley TH, Kullo IJ. Serum osteocalcin is associated with measures of insulin resistance, adipokine levels, and the presence of metabolic syndrome. Arterioscler Thromb Vasc Biol 2010;30(7):1474-8.

27. Kanazawa I. Osteocalcin as a hormone regulating glucose metabolism. World J Diabetes 2015;6(18):1345-54.

28. Berkner KL. The vitamin K-dependent carboxylase. Annu Rev Nutr 2005;25(1):127-49.

29. Shea MK, Gundberg CM, Meigs JB et al. $\gamma$-Carboxylation of osteocalcin and insulin resistance in older men and women. Am J Clin Nutr 2009;90(5):1230-5.

30. Hwang YC, Jeong IK, Ahn KJ et al. The uncarboxylated form of osteocalcin is associated with improved glucose tolerance and enhanced $\beta$-cell function in middle-aged male subjects. Diabetes Metab Res Rev 2009;25(8):768-72.

31. Lee NK, Sowa H, Hinoi E et al. Endocrine regulation of energy metabolism by the skeleton. Cell 2007;130(3):456-69.

32. Hussein AG, Mohamed RH, Shalaby SM et al. Vitamin K2 alleviates type 2 diabetes in rats by induction of osteocalcin gene expression. Nutrition 2018;47:33-8.

33. Desbois C, Hogue DA, Karsenty G. The mouse osteocalcin gene cluster contains three genes with two separate spatial and temporal patterns of expression. J Biol Chem 1994;269(2):1183-90.

34. Sakamoto N, Nishiike T, Iguchi $\mathrm{H}$ et al. Relationship between acute insulin response and vitamin $\mathrm{K}$ intake in healthy young male volunteers. Diabetes Nutr Metab 1999;12(1):37-41.

35. Yoshida M, Booth SL, Meigs JB et al. Phylloquinone intake, insulin sensitivity, and glycemic status in men and women. Am J Clin Nutr 2008;88(1):210-5.

36. Pittas AG, Harris SS, Eliades $M$ et al. Association between serum osteocalcin and markers of metabolic phenotype. J Clin Endocrinol Metab 2009;94(3):827-32.

37. Pollock NK, Bernard PJ, Gower BA et al. Lower uncarboxylated osteocalcin concentrations in children with prediabetes is associated with $\beta$-cell function. J Clin Endocrinol Metab 2011;96(7):1092-9.

38. Asemi Z, Raygan F, Bahmani F et al. The effects of vitamin D, $\mathrm{K}$ and calcium co-supplementation on carotid intima-media thickness and metabolic status in overweight type 2 diabetic patients with CHD. Br J Nutr 2016;116(2):286-93.

39. Choi HJ, Yu J, Choi H et al. Vitamin K2 supplementation improves insulin sensitivity via osteocalcin metabolism: A placebo-controlled trial. Diabetes Care 2011;34(9):147. 
40. Juanola-Falgarona M, Salas-Salvadó J, Estruch R et al. Association between dietary phylloquinone intake and peripheral metabolic risk markers related to insulin resistance and diabetes in elderly subjects at high cardiovascular risk. Cardiovasc Diabetol 2013;12:7.

41. Varsha MK, Thiagarajan R, Manikandan R et al. Vitamin K1 alleviates streptozotocin-induced type 1 diabetes by mitigating free radical stress, as well as inhibiting NF- $\mathrm{KB}$ activation and iNOS expression in rat pancreas. Nutrition 2015;31(1):214-22.

42. Liang Y, Tan A, Liang D et al. Low osteocalcin level is a risk factor for impaired glucose metabolism in a Chinese male population. J Diabetes Investig 2016;7(4):522-8.

43. Suksomboon N, Poolsup N, Darli Ko Ko H. Effect of vitamin K supplementation on insulin sensitivity: a meta-analysis. Diabetes Metab Syndr Obes 2017;10:169-77.

44. Ferron M, Hinoi E, Karsenty G et al. Osteocalcin differentially regulates beta cell and adipocyte gene expression and affects the development of metabolic diseases in wild-type mice. Proc Natl Acad Sci USA 2008;105(13):5266-70.

45. Mizokami A, Yasutake Y, Gao J et al. Osteocalcin Induces release of glucagon-like peptide-1 and thereby stimulates insulin secretion in mice. PLoS One 2013;8(2).

46. Shea MK, Booth SL, Massaro JM et al. Vitamin K and vitamin D status: Associations with inflammatory markers in the framingham offspring study. Am J Epidemiol 2007;167(3):313-20.

47. Vervoort LMT, Ronden JE, Thijssen HHW. The potent antioxidant activity of the vitamin $\mathrm{K}$ cycle in microsomal lipid peroxidation. Biochem Pharmacol 1997;54(8):871-6.

48. Ohsaki Y, Shirakawa H, Hiwatashi K et al. Vitamin K suppresses lipopolysaccharide-induced inflammation in the rat. Biosci Biotechnol Biochem 2006;70(4):926-32.

49. Reddi K, Henderson B, Meghji S et al. Interleukin 6 production by lipopolysaccharide-stimulated human fibroblasts is potently inhibited by naphthoquinone (vitamin k) compounds. Cytokine 1995;7(3):287-90.

50. Li J, Lin JC, Wang $\mathrm{H}$ et al. Novel role of vitamin $\mathrm{K}$ in preventing oxidative injury to developing oligodendrocytes and neurons. J Neurosci 2003;23(13):5816-26.

51. del Pino J, Martín-Gómez E, Martín-Rodríguez M et al. Influence of sex, age, and menopause in serum osteocalcin (BGP) levels. Klin Wochenschr 1991;69(24):1135-8. 